\title{
A SOIL CORE SAMPLER WITH PROVISION FOR CUTTING SUCCESSIVE LAYERS
}

\author{
Reijo Heinonen \\ Department of Agricultural Chemistry, University of Helsinki
}

Received May 28, 1960

For about ten years the author has been using the type of core sampler illustrated by Figs. 1 to 3 in bulk density and related determinations. As the device enables rapid working, it has also found application in such investigations in which the sample need not necessarily have an accurate volume if only it is representative of a given soil layer. Consequently, it has also been used by the author's colleagues, for instance in investigating the movement of top dress nitrogen and boron in the soil.

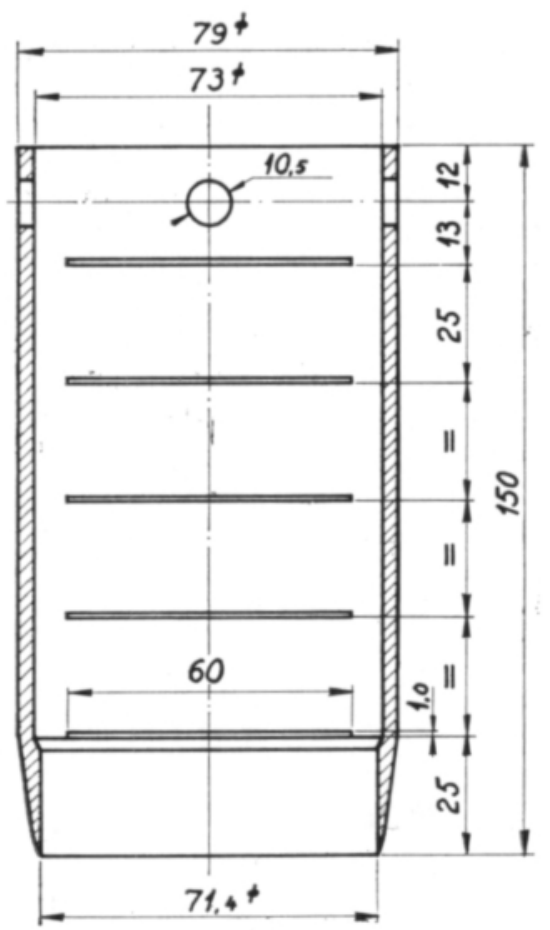

Fig. 1. 
A characteristic feature of this sampling cylinder consists of slits made at equal spacing in its mantle, and intended for the insertion of a blade by which a layer of the desired thickness can be cut off from the soil core in the cylinder. The separated part drops out when the cylinder is tilted, while the blade keeps the rest of the soil core in place. In the shaking out of the separated part, the lower end of the cylinder is closed with the flat of the hand, or with a piece of wood held in place by the

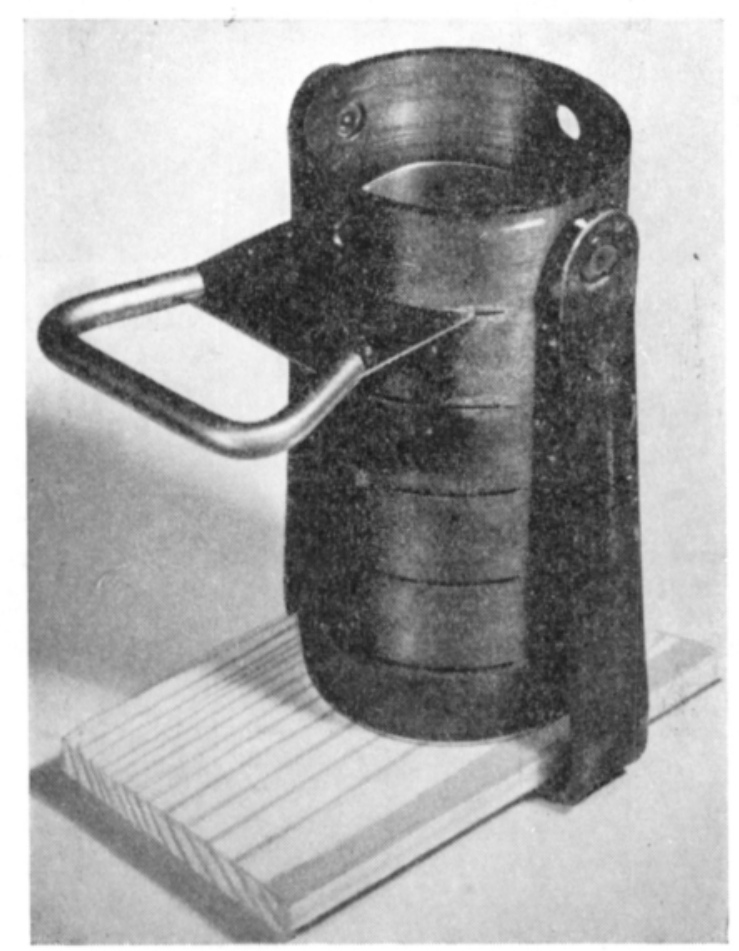

Fig. 2.

handle that has been turned down (Fig. 2). Often it is advisable to leave unused the lowest section of the sample, which is most difficult to detach and has a broken lower surface. The cylinder is made of case-hardened tool steel and is so dimensioned that a sample of $25 \mathrm{~mm}$ thickness has a volume of $100 \mathrm{cc}$.

The cutting blade is sharpened on its upper side only in order to reduce its tendency to curve upwards in compact soil samples. In some instances the potential departure of the blade from the direction square to the cylinder axis may still imply an excessive source of error. In such a case it is possible to employ the emptying plunger shown in Fig. 3. The required length of the soil core is simply pushed out through the upper end of the cylinder and cut off with a knife.

Various kinds of auxiliary equipment have been used for driving the cylinder into the soil, depending on the compactness of the soil and the required accuracy of 


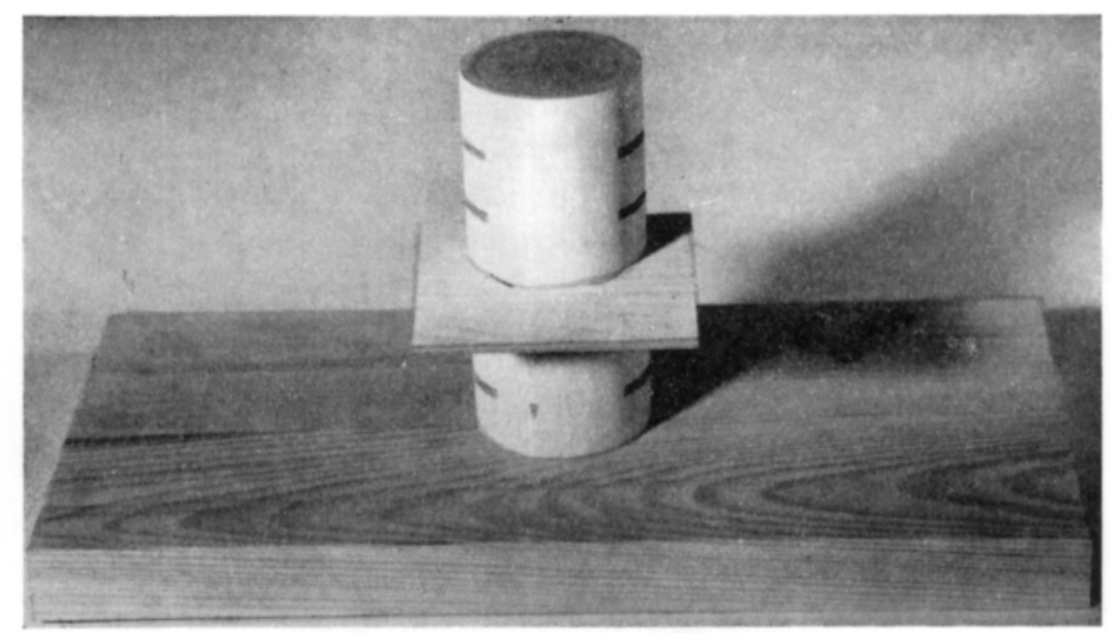

Fig. 3.

the operation. Into loose soil, the cylinder is pressed by hand (either directly or with the aid of an extension rod with crossbar handles), while a hammer has to be used if the soil is dense. The simplest procedure in this case is to interpose a piece of wood on top of the cylinder. However, the cylinder can be more accurately guided on its way into the soil with the Uhland-type sliding hammer (2). The handle (Fig. 2) can be left attached and used for loosening and pulling out the cylinder.

Considering the size of the required sample, a smaller cylinder would often be sufficient but the possible errors in the volume proportions will then be greater (1). For instance, we have observed that a cylinder $50 \mathrm{~mm}$ in diameter with a wall cross section in accordance with Fig. 1 sometimes exerts a wedge action in dry clay soil, thus producing considerable cracks. When the cylinder is driven down to its full depth, the cracks are partly within the cylinder causing excessive air volume in the lower part of the sample.

R E F E R E N E S

1) Jamison, V. C. \& Weaver, H. A. \& Reed, I. F. 1950. A hammer-driven soil-core sampler. Soil Sci. $69: 487-496$.

2) Uhland, R. E. 1949. Physical properties of soils as modified by crops and management. Soil Sci. Soc. Amer. Proc. 14: 361-366.

S E L O S T U:

KERROSNÅYTTEIDEN OTTOON SOVELLETTU MAANÄYTTEENOTTOLIERIÖ

Reijo Heinonen

Helsingin yliopiston maanviljelyskemian laitos

Artikkelissa selostetaan kerrosnäytteiden ottoon sovelletun maanäytteenottolieriön rakenne ja käyttō. 